\title{
IMMUNOHISTOCHEMICAL EXPRESSION OF HER2 IN ADENOCARCINOMA OF THE STOMACH
}

\author{
Diego Michelon DE CARLI물 Marta Pires da ROCHA ${ }^{1}$, Luis Carlos Moreira ANTUNES ${ }^{1}$ and \\ Renato Borges FAGUNDES ${ }^{1,2}$
}

\begin{abstract}
Background - Worldwide, gastric cancer is the fourth cancer in incidence and the second most common cause of cancer death. Gastric cancer is asymptomatic in the early stages and very often diagnosed at advanced stages, determining a dismal prognosis. Expression of the HER 2 gene has been identified in about $20 \%$ of gastric cancer cases, and its hyper-expression is associated with poor prognosis. Objective - To investigate HER2 immunohistochemical expression in gastric adenocarcinoma and its relationship to the histological type and anatomic location. Methods - A cross-sectional retrospective study analyzed the immunohistochemical expression of HER2 in a sample of 48 specimens of gastric cancer. Immunohistochemical analysis were performed using avidin-biotin-peroxidase method with C-erb B2 (clone EP1045Y), as a primary antibody (Biocare Medical, USA). Standardized gastric adenocarcinoma's HER2 expression criteria has been used in the analysis of samples. Results - There were seven cases with reactivity for HER2. Five were of intestinal-type while two cases were of mixed-type in which the expression occurred in the intestinal component. It was identified a significant association of HER 2 expression in the intestinal subtype of gastric adenocarcinoma $(P=0.003)$. Regarding the anatomical site, HER2 was positive in only one $(16.6 \%)$ of the six proximal cases and six $(14.28 \%)$ of the 42 distal cases $(P=0.88)$. Conclusion - HER 2 immunoexpression was identified in $14.6 \%$ of the samples, and the expression was significantly associated to Lauren's intestinal subtype.
\end{abstract}

HEADINGS - Immunohistochemistry. Stomach neoplasms. erbB-2 genes.

\section{INTRODUCTION}

Worldwide, gastric cancer (GC) is the fourth cancer in incidence and the second most common cause of cancer death. GC is usually detected at advanced stages, determining an overall five year-survival rate of approximately $20 \%$ most countries, except in Japan where this rate is around $60 \%$ due to screening programs, staging systems and treatment ${ }^{(15)}$.

In southern Brazil, GC is the fourth most common cancer in men $(14,3 / 100,000)$ and the sixth in women $(8,4 / 100,000)^{(6)}$. In the 25 years-period from 1986 to 2010, the prevalence of GC in the central region of Rio Grande do Sul State, the most southern Brazilian state, was $1.6 \%{ }^{(19)}$.

The HER1, HER2, HER 3 and HER4 receptors (also known as erbB) were first identified in 1978. They are transmembranal protein-tyrosine kinases that bind to the epidermal growth factor - EGF - and other similar molecules. HER2 is a glycoprotein with $185 \mathrm{kD}$ product of the ERBB2 oncogene, which is located on the short arm of chromosome 17 (locus $21)^{(8,20)}$. There are evidences that patients with gastric adenocarcinoma with positive HER 2 expression have increased survival rate when trastuzumab is added to the chemotherapy regimen ${ }^{(2)}$.

The aim of this study was to investigate the HER2 immunoexpression in 48 specimens of gastric adenocarcinoma, and additionally study the association of this expression with Lauren's histological subtypes and the anatomical location of the lesions.

\section{METHODS}

We selected 48 specimens of adenocarcinoma from patients who had undergone gastrectomy. We used the hematoxylin and eosin (HE) slides to identify representative tumor areas and select the paraffin blocks for immunohistochemical analysis.

The paraffin-embedded samples were cut in $3 \mu$ thick sections, mounted on slides, fixed for two hours at $60^{\circ} \mathrm{C}$, and then deparaffinized in xylene and hydrated in a decreasing series of alcohol until water. After those steps, the endogenous peroxidase was blocked with $3 \%$ hydrogen peroxide in two 10 -minute baths. Antigen retrieval was performed in a microwave oven

${ }^{1}$ Hospital Universitário de Santa Maria, Departamento de Clínica Médica, Universidade Federal de Santa Maria; ${ }^{2}$ Programa de Pós Graduação Ciências em Gastroenterologia e Hepatologia, Universidade Federal do Rio Grande do Sul. Porto Alegre, RS, Brasil.

Correspondence: Prof. Renato Borges Fagundes. Avenida Grécia, 1000, ap. 1002 B - CEP: 91350-070 - Porto Alegre, RS, Brasil. Email: fagundesrb@gmail.com 
for 26 minutes at full power $(800 \mathrm{~W})$, with the slides immersed in TRIS-EDTA ( $\mathrm{pH}$ 9). Endogenous biotin and avidin were blocked using a commercial kit (DAKO) for 10 minutes, followed by rinsing sequentially in running water, distilled water and a PBS buffer. Slides were incubated overnight at a temperature of $4{ }^{\circ} \mathrm{C}$ to $8^{\circ} \mathrm{C}$ in a humid chamber with the C-erb B2 primary antibody (Monoclonal antibody, clone EP1045Y, 1:150, Biocare Medical, USA) for 12 hours. This was followed by two 5-minute baths in PBS buffer and incubation with the universal biotinylated secondary antibody (anti IgG) for 30 minutes and two further 5-minute baths in PBS buffer. After that, the slides were incubated with the streptavidin-biotin-peroxidase for 30 minutes and rinsed twice in PBS buffer. The reaction was revealed using a solution of PBS with diaminobenzidine (DAB). The slides were counter-stained with Harris's hematoxylin, dehydrated in a graded series of alcohol, cleared in three xylene rinses and mounted using synthetic balsam.

We used Hofmann's criteria for immunohistochemical expression of HER2. Hoffmann's criteria is based on the percentage of cells with membrane-like staining ${ }^{(11,12)}$. Grades are classified as follows: grade 0: no reaction or $<10 \%$ reactivity in tumor cells; grade $1+$ : weak reactivity $>10 \%$ of the tumor cells; with reactivity only in part of the membrane; grade $2+$ : moderate reactivity in $>10 \%$ of the cells, with staining across the lateral and basolateral membrane: grade $3+$ : strong reactivity with intense staining of the lateral and basolateral membrane in $>10 \%$ of the cells. We use breast cancer tissue HER2 positive as external positive control. We consider reactivity for immunohistochemistry cases with strong and moderatappo $(2+/ 3+)$ intensity, and cases with low intensity and without reactivity as negative.

Cases that expressed grades $0,1+$ or $2+$ had a second analysis to confirm the finding. In these cases, we performed a new immunohistochemistry assessment in a sample from different site of the tumor. All slides were examined by a pathologist with expertise in the pathology of the digestive tract (MPR).

The institutional Ethics Committee approved the study protocol under CAAE number 0115.0.243.000-11.

\section{RESULTS}

The sample consisted of 42 distal tumors and 6 proximal tumors. According to Lauren's classification 21 were of intestinal subtype, 20 diffuse subtype, and 7 of mixed subtype. The clinical stages of distal tumors were: IA (2 / 4.8\%), IB
(11/26.2\%), II (7 / 16.7\%), IIIA (9/21.4\%), IV (13/30.9\%). The 6 proximal tumors clinical stages were: IB $(1 / 16.7 \%)$, II (1/ 16.7\%), IIIB (1/16.7\%) e stage IV (3/ 50\%).

The grade of HER2 immunoexpression was, as follows: 0 in $40(83.3 \%)$ specimens, $1+$ in $1(2.1 \%), 2+$ (equivocal) in 4 $(8.3 \%)$ and $3+$ in $3(6.3 \%)$. Seven specimens presented HER 2 reactivity immunoexpression, corresponding to $14.6 \%$ of the sample. Of the 20 cases of diffuse subtype, none expressed HER2; 5 of the 21 intestinal subtype cases expressed HER2, which corresponds to $14.28 \%$ of intestinal subtype cases. Of the seven mixed subtype cases, two expressed HER2 only in the intestinal component. There was a significant association of the tumor intestinal component with HER2 expression $(P=0.003)$. Of the six proximal lesions, only one $(16.6 \%)$ expressed HER2. Of the 42 distal lesions, 2 were $3+$ and 4 were $2+$ (equivocal). There were no changes in the results of the repeated assessment for cases with grades 0 , $1+$ or $2+$, therefore we did not see heterogeneity response in our sample. There was no statistical significance for the association of HER 2 expression with anatomical location $(P=0.88)($ Table 1$)$.

There was no association between HER 2 status and tumor stage. Four cases with expression $2+$ were in stages IB (01), II (01) and IIIA (02). Three cases with expression 3+ were in IB (02) and IV (01) (Figure 1).

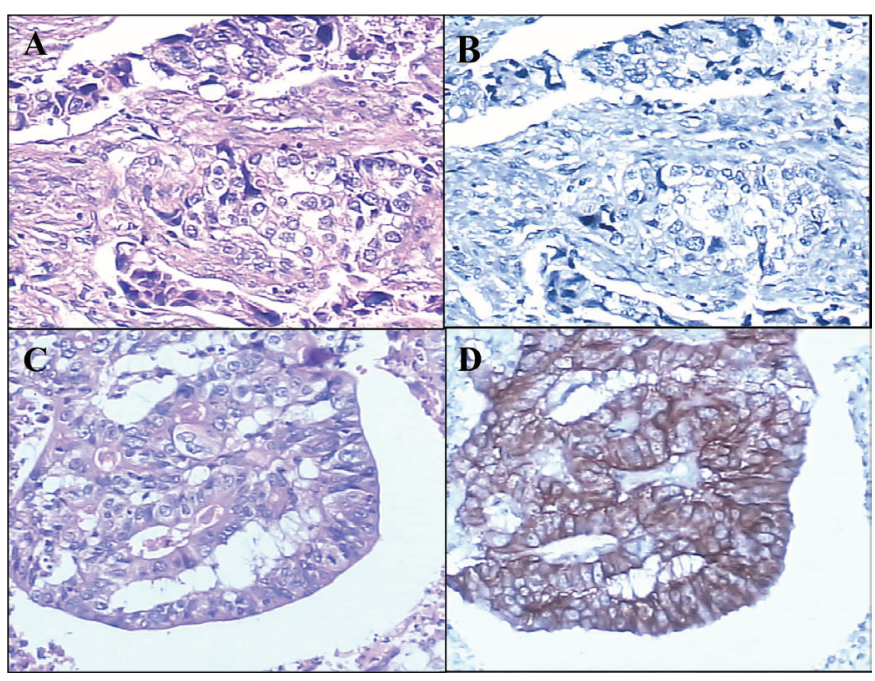

FIGURE 1. Lauren's diffuse subtype of adenocarcinoma at 200X magnification, HE staining (A) and HER2 negative (B). Lauren's intestinal subtype adenocarcinoma at 200X magnification, HE staining (C) and HER 2, reactive $3+(\mathrm{D})$.

TABLE 1. Relation of HER2 immunohistochemical expression with Lauren's histological subtypes and anatomical location of gastric adenocarcinoma

\begin{tabular}{|c|c|c|c|c|c|c|c|}
\hline Proximal & 0 & 1 & 0 & 3 & 2 & - & 6 \\
\hline Distal & 0 & 4 & 2 & 17 & 14 & 5 & 42 \\
\hline Total & 0 & 5 & 2 & 20 & 16 & 5 & 48 \\
\hline
\end{tabular}

$* * P=0.003$ 


\section{DISCUSSION}

In the present study, we found an overall rate of $14.6 \%$ reactivity for HER2 immunoexpression. We found a significant association between HER2 expression in the intestinal subtype, while no association was found with the diffuse type. In both cases of the mixed type, only the intestinal component of the tumor was reactive for HER2.

Our findings are very similar to those found in most American and European studies, where the prevalence rates of HER 2 range from $10 \%$ to $22.8 \%$, with the intestinal histological subtype being predominant in all the studies. Regarding anatomical location similar finding have been reported, with no difference between proximal and distal tumor, as we have found in our study ${ }^{(3,9,10,14,18,21)}$.

Most studies conducted in Asia have also reported reactivity rates of $11.7 \%$ to $15.74 \%$, similar to our findings, as well as the predominance of HER 2 expression in the intestinal subtype ${ }^{(11,16,17,22)}$. Only one study from Japan showed different prevalence of HER 2 expression regarding to anatomical distribution. In that study, the prevalence of HER 2 expression was found to be three times greater in proximal tumors ${ }^{(17)}$.

ToGA trial was a phase III, randomized, controlled, multicenter study, designed to test the efficacy and safety of an anti-HER 2 drug (trastuzumab) in association with chemotherapy for treatment of advanced gastric cancer. This trial showed that in patients whose lesions were HER2 positive the addition of trastuzumab to the basic chemotherapy regime increased the survival rate to 16 months compared with 11.8 months in patients submitted to chemotherapy regime alone. This study found a rate of $22.1 \%$ for HER2 expression. The expression of HER 2 was higher in intestinal subtype lesions when compared with the diffused/mixed subtypes, similar to our findings. However, unlike our findings, this study found an increased expression of HER 2 in proximal tumors. The low expression of HER2 in proximal lesions in our study could be explained by the small number of proximal tumors in our sample ${ }^{(2)}$. The higher prevalence of HER 2 in the ToGA study in relation to our findings and those of other studies may be due to ToGA's design, where the goal of determining the effectiveness of trastuzumab in HER 2 positive lesions may have led to an overestimation of the prevalence of HER2 in their results.

In Brazil, the first study conducted by Begmani et al. in 2005, analyzed the immunohistochemical expression in 462 cases and found the prevalence of HER 2 expression in $12 \%$. The HER 2 expression was predominant in intestinal type, and they found no difference related to the anatomical site. Although that study showed results that are similar to ours, the frequency of HER 2 expression may have been underestimated, since they used immunohistochemical grading score for breast cancer, in which the entire membrane should be stained, and not only the lateral and basolateral walls ${ }^{(5)}$. The second study conducted in Rio Grande do Sul by Cirne-Lima et al. in 2009 identified HER 2 positivity in $5.4 \%$ of 37 cases. This low rate may be due to the immunohistochemical score used, the smaller sample and the low percentage of the intestinal subtype ${ }^{(7)}$. Our study, in addition to using HER2 gastric immunohistochemical criteria (that are specific criteria for the analysis of gastric cancer) has an equivalent percentage of intestinal and diffuse tumors, thus avoiding the predominance of a histological subtype, which would probably influence the expression of HER2. On the other side, three studies conducted recently in Brazil and using Hoffmann's criteria ${ }^{(1,4,13)}$ found a global prevalence of $10 \%$ to $17 \%$. This studies also found association of HER 2 with intestinal subtype and only one, like ours, accessed but did not find association with the anatomical site ${ }^{(4)}$.

Analyzing previous studies on the expression of HER2 separately in the intestinal and diffuse subtypes, we find a prevalence in intestinal type ranging from $6.1 \%$ to $28.57 \%$, and in the diffuse type from 0.7 to $13,43 \%^{(3,5,7,10-12,16-18,21,22)}$. Kataoka and colleagues, in their review of mixed subtype specimens found results similar to ours and found HER2 expressed only in the intestinal component ${ }^{(16)}$. This finding supports the evidence that the expression of HER2 has a more consistent association with Lauren's intestinal subtype.

Our study has limitations inherent to retrospective studies. The small number of proximal cases may have biased the data regarding the association of HER2 expression with anatomical location. Another limitation is the non-use of the FISH technique to confirm the immunohistochemical expression of HER2 in cases classified as $2+$ (equivocal). Cases classified as $2+$, when evaluating gene amplification by $\mathrm{FISH}$, the positivity rate ranges from $36.4 \%$ to $66 \%$. This issue is relevant because only those cases with grades $3+$ and $2+$ that are positive for FISH present evidence of more benefit of adding trastuzumab to the chemotherapy regimen $^{(2,10,15,21)}$. With the advent of trastuzumab, it has become important determine accurately HER 2 expression in gastric adenocarcinoma in order to identify patients who will benefit from its use. Therefore, we need new studies that aim to identify HER 2 positivity in gastric cancer. Those new studies should adopt a prospective design and appropriate score for HER2 expression as well as the use of FISH for confirmation.

\section{CONCLUSION}

Our study demonstrated HER2 immunoexpression in $14.6 \%$ of gastric adenocarcinoma. The expression was predominant in Lauren's intestinal subtype. There was no difference in the expression related to anatomical location of the lesions or association with the clinical stage.

\section{Authors' contributions}

Fagundes, RB, De Carli, DM and Antunes, LCM participated in the conception and design of the study. Rocha, MP and De Carli DM conducted the histological and immunohistochemical analysis. Fagundes RB performed the analyis and interpretation of the data and wrote the manuscript. All the authors approved and assumed public responsibility for the manuscript. 
De Carli DM, Rocha MP, Antunes LCM, Fagundes RB. Expressão imunoistoquímica do HER2 no adenocarcinoma de estômago. Arq Gastroenterol. 2015,52(2):152-5.

RESUMO - Contexto - O câncer gástrico ocupa o quarto lugar em incidência no mundo e é a segunda causa de óbito por neoplasia maligna. Por ser assintomático nas fases iniciais, na maioria das vezes, é diagnosticado em fases avançadas. A expressão do gene HER2 tem sido identificada em cerca de $20 \%$ dos casos de câncer gástrico e, sua hiper-expressão está associada a um pior prognóstico nestes pacientes. Objetivo - Investigar a expressão imunoistoquímica do HER2 em espécimes de adenocarcinoma gástrico e sua relação com a classificação histológica e localização anatômica. Métodos - Estudo transversal, retrospectivo, no qual foi analisada a expressão imunoistoquímica para o HER2, em uma amostra de 48 espécimes de câncer gástrico, através da técnica de imunoistoquímica, pelo método avidina-biotina-peroxidase utilizando anticorpo primário C-erb B2, clone EP1045Y (Biocare Medical, USA). Resultados - Foram encontrados sete casos reativos para o HER2; destes, cinco eram casos de adenocarcinoma do tipo intestinal e dois eram casos do tipo misto, porém, nestes, a expressão ocorreu no componente intestinal, o que determinou uma associação significante da expressão de HER2 com o componente intestinal do adenocarcinoma gástrico $(P=0,003)$. Em relação ao local anatômico, HER2 foi reativo em apenas um $(16,6 \%)$ de seis casos proximais e seis $(14,28 \%)$ dos 42 casos distais $(P=0,88)$. Conclusão - A expressão de HER2 ocorreu em $14,6 \%$ da amostra, associada significativamente ao subtipo intestinal de Lauren.

DESCRITORES - Imuno-histoquímica. Neoplasias gástricas. Genes erbB-2.

\section{REFERENCES}

1. Abrahão-Machado LF, Jácomé AAA, Wohnrath DR, Santos JS, Carneseca EC, Fregmani JHTG, Scapulatempo-Neto C. HER2 in Gastric Cancer: Comparative análysis of three different antibodies using whole-tissue sections and tissue microarrays. World J Gastroenterol. 2013;19(38):6438-46.

2. Bang, YJ, Cutsem E, Feyereislova A, Chung HC, Shen L, Sawaki A, et al. Trastuzumab in combination with chemotherapy versus chemotherapy alone for treatment of HER2-positive advanced gastric or gastro-oesophageal junction cancer (ToGA): a phase 3, open-label, randomised controlled trial. Lancet. 2010;376(9742):687-97.

3. Barros-Silva JD, Leitao D, Afonso L, Vieira J, Dinis-Ribeiro M, Fragoso M, et al. Association of ERBB2 gene status with histopathological parameters and disease-specificsurvival in gastric carcinoma patients. Br J Cancer. 2009;100(3): 487-93.

4. Begmani MD, Fukuda E, Fregnani JHTG, Nonogaki S, Montagnini AL, Costa WL, Soares FA. Prognostic implications of Altered Human Epidermal Growth Factor Receptor (HERs) in Gastric Carcinomas: HER2 and HER3 are predictors of Poor Outcome. J Clin Oncol. 2011;29:3030-6.

5. Begnami MD, Campos AH, Silva E, Montagnini AL, Nascimento CF, Nonogaki S, Soares FA. Expressão imuno-histoquimica de c-erb-B2 e p53 em carcinomas gástricos. J Bras Pato Med Lab 2005;41(4):279-86.

6. Brasil. Ministério da Saúde.Secretaria de Atenção à Saúde.Instituto Nacional de Câncer.Coordenação de Prevenção e Vigilância. Estimativa 2014: Incidência de câncer no Brasil. Rio de Janeiro. INCA, 2013.

7. Cirne-Lima FK, Rosa AS, Kulczynski JM, Mattana DS, Corezolla K, Moreira LF. Immunohistochemical expression of HER-2/NEU-CERBB-2 in patients with adenocarcinoma of the stomach. Rev Col Bras Cir. 2009;36(2):131-4.

8. Fukushige S, Matsubara K, Yoshida M, Sasaki M, Suzuki T, Semba K, Toyoshima $\mathrm{K}$, Yamamoto T. Localization of a novel v-erbB-related gene, c-erbB-2, on human chromosome 17 and its amplification in a gastric cancer cell line. Mol Cell Biol. 1986;6(3):955-8.

9. Gomez-Martin C, Garralda E, Echarri MJ, Ballesteros A, Arcediano A, Rodriguez-Peralto JL, et al. HER2/neu testing for anti-HER2-based therapies in patients with unresectable and/or metastatic gastric cancer. J Clin Pathol. 2012;65(8):751-7.

10. Grabsch H, Sivakumar S, Gray S, Gabbert HE, Muller W. HER2 expression in gastric cancer: Rare, heterogeneous and of no prognostic value - conclusions from 924 cases of two independent series. Cell Oncol. 2010;32(1-2):57-65.
11. He C, Bian XY, Ni XZ, Shen DP, Shen YY, Liu H, Shen ZY, Liu Q. Correlation of human epidermal growth factor receptor 2 expression with clinicopathological characteristics and prognosis in gastric cancer. World J Gastroenterol. 2013;19(14):2171-8

12. Hofmann M, Stoss O, Shi D, Buttner R, Van V, Kim W, et al. Assessment of a HER2 scoring system for gastric cancer: results from a validation study. Histopathology. 2008;52(7):797-805.

13. Jacomé AAA, Wohnrath DR, Scapulatempo Neto C, Carneseca EC, Martinez EZ, Santos JS. Prognostic value of epidermal growth factor receptors in gastrica cancer: a survival analisis by Weibull model incorporating long-term survivors Gastric Cancer. 2014;17:76-86.

14. Jorgensen JT. Targeted HER2 treatment in advanced gastric cancer. Oncology. 2010;78(1):26-33.

15. Kamangar F, Dores GM, Anderson WF. Patterns of cancer incidence, mortality, and prevalence across five continents: defining priorities to reduce cancer disparities in different geographic regions of the world. J Clin Oncol. 2006;24(14):2137-50.

16. Kataoka Y, Okabe H, Yoshizawa A, Minamiguchi S, Yoshimura K, Haga H, Sakai Y. HER2 expression and its clinicopathological features in resectable gastric cancer. Gastric Cancer. 2013;16(1):84-93.

17. Kim KC, Koh YW, Chang HM, Kim TH, Yook JH, Kim BS, et al. Evaluation of HER2 protein expression in gastric carcinomas: comparative analysis of 1,414 cases of whole-tissue sections and 595 cases of tissue microarrays. Ann Surg Oncol. 2011;18(10):2833-40.

18. Kunz PL, Mojtahed A, Fisher GA, Ford JM, Chang DT, Balise RR, et al HER2 expression in gastric and gastroesophageal junction adenocarcinoma in a US population: clinicopathologic analysis with proposed approach to HER2 assessment. Appl Immunohistochem Mol Morphol. 2012;20(1):13-24.

19. Rampazzo A, Mott GL, Fontana K, Fagundes RB. Gastric adenocarcinoma trends in the central region of Rio Grande do Sul (Southern Brazil): what has changed in 25 years? Arq Gastroenterol. 2012;49(3):178-83.

20. Rose JS, Bekaii-Saab TS. New developments in the treatment of metastatic gastric cancer: focus on trastuzumab. Onco Targets Ther. 2011;4:21-6.

21. Ruschoff J, Dietel M, Baretton G, Arbogast S, Walch A, Monges G, et al. HER2 diagnostics in gastric cancer-guideline validation and development of standardized immunohistochemical testing. Virchows Arch. 2010;457(3):299-307.

22. Zhou F, Li N, Jiang W, Hua Z, Xia L, Wei Q, Wang L. Prognosis significance of HER-2/neu overexpression/amplification in Chinese patients with curatively resected gastric cancer after the ToGA clinical trial. World J Surg Oncol. 2012;10(1):274. 